\title{
Evaluation of experimental alkali metal ion- ligand noncovalent bond strengths with DLPNO-CCSD(T) method
}

Cite as: J. Chem. Phys. 151, 014301 (2019); https://doi.org/10.1063/1.5099580

Submitted: 11 April 2019 . Accepted: 06 June 2019 . Published Online: 02 July 2019

Bholanath Maity (D), Yury Minenkov (D), and Luigi Cavallo (D)
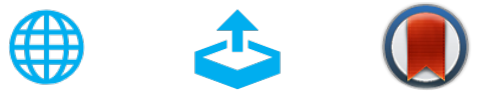

View Online

Export Citation

\section{ARTICLES YOU MAY BE INTERESTED IN}

Implementation of analytic gradients for CCSD and EOM-CCSD using Cholesky

decomposition of the electron-repulsion integrals and their derivatives: Theory and benchmarks

The Journal of Chemical Physics 151, 014110 (2019); https://doi.org/10.1063/1.5100022

A thermal orbital-free density functional approach

The Journal of Chemical Physics 151, 014103 (2019); https://doi.org/10.1063/1.5100231

Perspective: Computational chemistry software and its advancement as illustrated through three grand challenge cases for molecular science

The Journal of Chemical Physics 149, 180901 (2018); https://doi.org/10.1063/1.5052551

The Journal

of Chemical Physics

The Emerging Investigators Special Collection and Awards Recognizing the excellent work of early career researchers! 


\title{
Evaluation of experimental alkali metal ion-ligand noncovalent bond strengths with DLPNO-CCSD(T) method
}

\author{
Cite as: J. Chem. Phys. 151, 014301 (2019); doi: 10.1063/1.5099580 \\ Submitted: 11 April 2019 Accepted: 6 June 2019 • \\ Published Online: 2 July 2019
}

\author{
Bholanath Maity,' (D) Yury Minenkov, ${ }^{2, a)}$ (D) and Luigi Cavallo, (D) \\ AFFILIATIONS \\ ${ }^{1}$ King Abdullah University of Science and Technology (KAUST), Physical Science and Engineering Division (PSE), \\ KAUST Catalysis Center (KCC), 23955-6900 Thuwal, Saudi Arabia \\ ${ }^{2}$ Moscow Institute of Physics and Technology, Institutskiy Pereulok 9, Dolgoprudny, Moscow Region 141700, Russian Federation
}

${ }^{a}$ Authors to whom correspondence should be addressed:Yury.Minenkov@phystech.edu and Luigi.Cavallo@kaust.edu.sa

\begin{abstract}
We applied the domain based local pair natural orbital coupled cluster approach with single, double, and perturbative triple excitations, DLPNO-CCSD(T), to rationalize more than 130 experimental bond dissociation enthalpies collected in the work of Rodgers and Armentrout [Chem. Rev. 116, 5642-5687 (2016)] and involving alkali metal cations and versatile neutral organic and inorganic ligands ranging from common solvents to amino acids. In general, a remarkable agreement has been obtained between predicted and experimental alkali metal ionligand noncovalent bond strengths, highlighting a high degree of reliability of data assembled by Rodgers and Armentrout. In the case of some inconsistent experimental data given for some species, we pointed to a number for which best agreement with DLPNO-CCSD(T) calculations has been achieved. In addition, we refined a couple of $\Delta H_{0}$ for which DLPNO-CCSD(T) values turned out to be significantly different from their experimental counterparts. We suggest an application of the DLPNO-CCSD(T) to derive the reference values to train/validate force field and neural network methods to be further applied in molecular dynamic simulations to unravel the mechanisms in biological systems and alkali metal ion batteries.
\end{abstract}

Published under license by AIP Publishing. https://doi.org/10.1063/1.5099580

\section{INTRODUCTION}

Noncovalent interactions ${ }^{1,2}$ of alkali metal cations with versatile ligands and solvent functional groups are at the heart of many biological and industrially appreciated processes. ${ }^{3}$ Due to its multiple effects on the nervous system and blood properties, lithium salts are active ingredients of many pharmaceuticals against mental disorders. ${ }^{4-7}$ Furthermore, $\mathrm{Li}^{+}$ions exhibit antiviral activity against DNA type viruses. ${ }^{8}$ Both sodium and potassium ions maintain the electrolyte balance in the body and are responsible for transportation of molecules across the cell membranes, a process known as the sodium-potassium pump. ${ }^{9}$ In addition, the $\mathrm{K}^{+}$ ion acts as a cofactor for certain enzymes such as pyruvate kinase. Even if rubidium and cesium have no known biological roles, these can replace intracellular functions of $\mathrm{K}^{+}$ions. ${ }^{10}$ Besides, sodium and potassium salts serve as food preservatives. When it comes to technological applications, alkali metal salts are used as components of glasses, ceramics, cement, soap, greases, stereoselective synthesis, nuclear reactors, nuclear fusion, and batteries and fuel cells. ${ }^{11}$ Moreover, $\mathrm{Li}^{+}$is a driving force in Li-ion batteries ${ }^{12}$ utilized in portable electronics, power tools, and electric vehicles. ${ }^{13}$ Like Liion batteries, remarkable progress has been made to develop $\mathrm{Na}$-ion batteries. $^{1}$

As the cation- $\pi$ interaction is predicted to be the strongest among other noncovalent interactions, ${ }^{15}$ it plays an important role in many above-mentioned applications, particularly in protein structure, molecular recognition, and enzyme catalysis. ${ }^{16-18}$ Therefore, the study of the thermochemical properties of cation-neutral association reactions is one of prime importance in versatile fields of contemporary interest. ${ }^{17,18}$ The high interest in these systems has led to the determination of a large number of ligand-alkali metal noncovalent bond strengths over the years, as excellently summarized 
by Rodgers and Armentrout recently. ${ }^{3}$ This kind of data collection represents a reference for years to come.

However, the reliability of compilations merging the data from a large number of sources is always questionable, unless each included experimental number is reconfirmed by a separate measurement carried out in a different scientific group (ideal situation). In reality, however, due to the complexity of the gas phase measurements often performed with custom-built equipment, and significant economic costs associated with experimental science in general, this is rarely the case. It is quite common that a physical observable is characterized either by a set of inconsistent values assembled from different sources or by a single number coming from the half-century-old measurement. In this scenario, electronic structure calculations can represent a powerful tool to validate databases assembled from different experimental sources. When keen attention is paid to inclusion of the effects arising from dispersion forces, ${ }^{19,20}$ subvalence and core-core correlation, ${ }^{20-26}$ basis set incompleteness and superposition errors, ${ }^{27,28}$ the results of chemical accuracy can be achieved. ${ }^{29-31}$ Until very recently, the only viable option for accurate calculations has been the canonical coupled cluster method with single, double, and perturbative triple excitations, $\operatorname{CCSD}(\mathrm{T}),{ }^{32}$ known as the "gold standard" in quantum chemistry. However, due to poor scaling with respect to the system size, $\mathrm{N}^{7}$, and slow convergence with respect to the basis set size, accurate $\operatorname{CCSD}(\mathrm{T})$ calculations are feasible only for small model systems with up to a dozen of atoms. Recently, its local alternative DLPNO-CCSD(T) approximation ${ }^{33-35}$ has been developed and shown to be applicable with the most strict criteria to the systems with up to dozens of atoms keeping the accuracy of the parent method. ${ }^{20,24,36-40}$ With this background, we rationalized experimentally measured noncovalent bond dissociation energies of ligands from alkali metal cations according to the reaction of the following equation:

$$
\mathrm{M}^{+}(\mathrm{L})_{\mathrm{x}} \rightarrow \mathrm{M}^{+}(\mathrm{L})_{\mathrm{x}-1}+\mathrm{L}[\mathrm{x}=1,2]
$$

\section{COMPUTATIONAL DETAILS}

\section{A. Geometry optimization}

All geometry optimizations and vibrational frequency calculations have been performed with long-range dispersion corrected hybrid density functional, $\omega \mathrm{B} 97 \mathrm{xD}^{41}$ as implemented in the Gaussian09 program package. ${ }^{42}$ The default values were adopted for the self-consistent field and geometry optimization convergence criteria. Numerical integration of the exchange-correlation (XC) terms was performed using the tighter-than-default "ultrafine" option (pruned, 99 radial shells, and 590 angular points per shell) to eliminate the potential numerical noise in energy second derivatives. ${ }^{43-45}$ For hydrogen, lithium, carbon, nitrogen, oxygen, fluorine, sodium, phosphorus, sulfur, and chlorine, we used nonrelativistic all electron correlation consistent polarized valence double- $\zeta$ basis set augmented with diffuse functions, aug-cc-pVDZ. ${ }^{46,47}$ Potassium, bromine, rubidium, and cesium were treated with pseudopotential based aug-cc-pVDZ-PP basis sets of Hill and Peterson. All basis sets were collected from a correlation consistent basis set repository. ${ }^{49}$ The 10 electrons of potassium and bromine, 28 electrons of rubidium, and 46 electrons of cesium were described with fully relativistic Stuttgart/Köln pseudopotentials. ${ }^{50}$ If several conformations/spatial structures could be possible for some molecules, the structure of the most stable one was found by geometry optimization of manually generated conformations/spatial structures. Harmonic force constants were computed at the optimized geometries to characterize the true energy minima. The ideal gas, rigid-rotor harmonic-oscillator approximation was applied to evaluate the thermal and entropic contribution terms, which are used to derive the total enthalpies at $298.15 \mathrm{~K}$.

Noteworthy, most of the experimental bond dissociation energies are given as enthalpies at $0 \mathrm{~K}\left(\Delta H_{0}\right)$ and others are enthalpies at $298.15 \mathrm{~K}\left(\Delta H_{298}\right)$. To make the study consistent, all $\Delta H_{298}$ experimental values were converted to $\Delta H_{0}$ via the following procedure. First, $Z P E$ and enthalpy corrections were calculated at the $\omega \mathrm{B} 97 \mathrm{xD} /$ aug-cc-pVDZ(-PP) level. Then, the subtraction of the enthalpy correction from the experimental $\Delta H_{298}$ was followed by the addition of the $Z P E$ correction to arrive at the final $H_{0}$ energy change.

\section{B. Single-point energies evaluations}

All single-point energy evaluations were performed with the DLPNO-CCSD(T) method m $^{3-35}$ as implemented in the ORCA suite of programs. ${ }^{51}$ Tighter than the default "TightPNO" DLPNO settings (TCutPairs $=10^{-5}$, TCutPNO $=10^{-7}$, and TCutMKN $=10^{-3}$ ) were used, as recommended, for applications where the most accurate values are targeted.

The following triple and quadruple- $\zeta$ correlation consistent basis sets were used in the present work. Hydrogen, carbon, nitrogen, oxygen, fluorine, phosphorus, sulfur, and chlorine were described with the all electron correlation consistent polarized and diffuse augmenting functions aug-cc-pVnZ basis sets of Dunning and co-workers. ${ }^{46,53}$ Lithium and sodium were treated with all electron correlation consistent polarized core valence basis sets of Peterson and Dunning ${ }^{47}$ augmented with diffuse functions, aug-cc-pwCVnZ. Potassium, rubidium, cesium, and bromine were described with the pseudopotential based diffuse augmented correlation consistent polarized core valence aug-cc-pwCVnZ-PP basis sets of Peterson and co-workers. ${ }^{48,54}$ The 10 core electrons of potassium and bromine, the 28 core electrons of rubidium, and the 46 core electrons of cesium were described with Stuttgart-type fully relativistic effective core potentials. ${ }^{50,55,56}$

To eliminate the effects of basis set incompleteness (BSI) and basis set superposition error (BSSE), we used the extrapolation schemes for HF and correlation energies of individual species suggested by Helgaker et al. ${ }^{57-59}$ [see Eqs. (2) and (3)]. For two adjacent triple- and quadruple- $\zeta$ basis sets,

$$
\begin{aligned}
& E_{H F}^{n}=E_{H F}^{\infty}+\alpha e^{-1.63 n}, \\
& E_{c o r l}^{n}=E_{c o r l}^{\infty}+\beta n^{-3},
\end{aligned}
$$

where $\mathrm{n}=3$ and 4 for triple- and quadruple- $\zeta$ basis sets, $\mathrm{E}_{\mathrm{HF}}{ }^{\infty}$ and $\mathrm{E}_{\mathrm{corl}} \infty$ are $\mathrm{HF}$ and correlation energies at the complete basis set (CBS) limit, respectively, and $\alpha$ and $\beta$ are parameters to be obtained from a system of the two equations. The total $\Delta H_{0}$ at the CBS limit for each reaction $(\mathrm{A}+\mathrm{B} \rightarrow \mathrm{C})$ was evaluated via the following equation: 


$$
\begin{aligned}
\triangle Z P E_{D L P N O-C C S D(T)}= & E_{H F}^{\infty}(C)+E_{c o r l}^{\infty}(C)+Z P E_{\text {corr }}^{\omega B 97 x D}(C) \\
& -\left(E_{H F}^{\infty}(A)+E_{c o r l}^{\infty}(A)+Z P E_{\text {corr }}^{\omega B 97 x D}(A)\right. \\
& \left.+E_{H F}^{\infty}(B)+E_{\text {corl }}^{\infty}(B)+Z P E_{\text {corr }}^{\omega B 97 x D}(B)\right),
\end{aligned}
$$

where $Z P E_{\text {corr }}^{\omega B 97 x D}$ is the $H_{0}$ correction at $\omega \mathrm{B} 97 \mathrm{xD} /$ aug-cc-pVDZ.

An effect of the counterpoise (CP) correction on the dissociation enthalpies turned out to be of a few tenths of $\mathrm{kJ} / \mathrm{mol}$; see Table S1 in the supplementary material. For these reasons, all enthalpies in this work are not corrected for CP.

\section{RESULTS AND DISCUSSION}

This section is organized into two parts. First, we assess the accuracy of the DLPNO-CCSD $(\mathrm{T})$ method in reproducing the most reliable experimental alkali metal ions-ligand noncovalent bond dissociation $\Delta H_{0}$ with the uncertainty of not greater than $4.0 \mathrm{~kJ} / \mathrm{mol}$. Second, as the method turned out to perform well, we applied it to rationalize the experimental energies corresponding to the dissociation of noncovalently bonded ligands from the systems $\mathrm{M}^{+}-\mathrm{L}$. The reactions of lithium, sodium, potassium, rubidium, and cesium cations are considered separately. Furthermore, we proceed to the simultaneous dissociation of the first ligands from the systems like (L) $\mathrm{M}^{+}-\mathrm{L}$.

\section{A. Accuracy of the DLPNO-CCSD(T) method}

Despite excellent performance of the DLPNO-CCSD(T) approach in reproducing coinage metals-noncovalently bonded ligands dissociation enthalpies, ${ }^{39}$ reaction energies, ${ }^{20,24,40,76,77}$ gas phase heats of formation of inorganic ${ }^{36}$ and organic substances, ${ }^{38,78,79}$ a few recent works revealed some limitations as well. Chen and coworkers found that DLPNO-CCSD(T) method significantly overestimated gas phase bond dissociation energies in proton bound organic dimers. ${ }^{80}$ Similarly, DLPNO-CCSD(T) gas phase transition metal-ligand dissociation enthalpies in large organometallic complexes (WCCR10 dataset) ${ }^{81}$ were reported to be substantially larger compared to their experimental counterparts. ${ }^{82}$ As noncovalent interactions contribute significantly to the chemical bonds for which the above-mentioned failures were obtained, the DLPNO$\operatorname{CCSD}(\mathrm{T})$ approximation has been carefully tested in reproducing 26 alkali metal ions-ligands bond $\Delta H_{0}$. Only $\mathrm{Li}^{+}-\mathrm{Cs}^{+}$systems with the $\Delta H_{0}$ uncertainty within $\pm 4 \mathrm{~kJ} / \mathrm{mol}$ have been included in the validation set; see Table $\mathrm{I}^{33,35}$ In case of a few experimental measurements, an average $\Delta H_{0}$ has been taken. The overall mean unsigned error (MUE)/mean signed error (MSE) are 5.0 and $-1.6 \mathrm{~kJ} / \mathrm{mol}$, respectively. A scatter plot based on experimental ( $\mathrm{x}$ axis) and DLPNO-CCSD(T)/CBS (y axis) values is given in Fig. 1. The calculated squared Pearson correlation coefficient $\mathrm{R}^{2}=0.94$ demonstrates good fit between experimental and theoretical values indicating the DLPNO-CCSD $(\mathrm{T})$ method to be a reliable tool for calculation of alkali metal ions-ligands noncovalent bond dissociation energies.

For further validation of the method used for optimization, we have reoptimized aforementioned 26 species using $\omega \mathrm{B} 97 \mathrm{xD} / \mathrm{aug}$ cc-pVTZ(-PP) and PBE/aug-cc-pVDZ(-PP) separately. Thereafter, those optimized geometries were used for single point calculations

\begin{tabular}{|c|c|c|}
\hline Systems & Expt. & Calculated \\
\hline$(\mathrm{CO}) \mathrm{Li}^{+}-\mathrm{CO}$ & $36.0 \pm 4.0^{60}$ & 44.3 \\
\hline$\left(\mathrm{NH}_{3}\right) \mathrm{Na}^{+}-\mathrm{NH}_{3}$ & $99.6 \pm 1.0^{61}$ & 93.4 \\
\hline $\mathrm{Na}^{+}-\mathrm{CH}_{3} \mathrm{CO}_{2} \mathrm{CH}_{3}$ & $123.2 \pm 3.0^{62}$ & 130.8 \\
\hline $\mathrm{Na}^{+}-\mathrm{CH}_{3} \mathrm{CHO}$ & $113.0 \pm 3.0^{63-65}$ & 121.0 \\
\hline $\mathrm{Na}^{+}$-pyrazine & $107.0 \pm 4.0^{66}$ & 103.6 \\
\hline $\mathrm{Na}^{+}$-pyridine & $127.0 \pm 3.0^{66}$ & 132.1 \\
\hline $\mathrm{Na}^{+}$-pyrimidine & $103.0 \pm 4.0^{66}$ & 108.5 \\
\hline $\mathrm{K}^{+}-\mathrm{CH}_{3} \mathrm{CN}$ & $101.3 \pm 2.0^{67}$ & 101.3 \\
\hline$\left(\mathrm{CH}_{3} \mathrm{CN}\right) \mathrm{K}^{+}-\mathrm{CH}_{3} \mathrm{CN}$ & $89.2 \pm 2.0^{67}$ & 84.6 \\
\hline $\mathrm{K}^{+}-{ }^{\mathrm{n}} \mathrm{C}_{3} \mathrm{H}_{7} \mathrm{OH}$ & $83.0 \pm 4.0^{68}$ & 87.2 \\
\hline $\mathrm{K}^{+}-\mathrm{C}_{2} \mathrm{H}_{5} \mathrm{COOH}$ & $86.0 \pm 4.0^{68}$ & 96.1 \\
\hline $\mathrm{K}^{+}-\mathrm{CH}_{3} \mathrm{NH}_{2}$ & $78.7 \pm 4.0^{69}$ & 81.1 \\
\hline $\mathrm{K}^{+}-\left(\mathrm{CH}_{3}\right)_{2} \mathrm{NH}$ & $81.0 \pm 4.0^{69}$ & 81.5 \\
\hline$\left(\mathrm{H}_{2} \mathrm{O}\right) \mathrm{K}^{+}-\mathrm{H}_{2} \mathrm{O}$ & $67.0 \pm 4.0,^{70,71} 67.0^{72}$ & 61.2 \\
\hline $\mathrm{K}^{+}-\left(\mathrm{C}_{2} \mathrm{H}_{5}\right)_{2} \mathrm{O}$ & $92.0 \pm 4.0^{69}$ & 90.3 \\
\hline $\mathrm{K}^{+}-\mathrm{CH}_{3} \mathrm{COC}_{2} \mathrm{H}_{5}$ & $95.0 \pm 4.0^{68}$ & 105.0 \\
\hline $\mathrm{K}^{+}-\left(\mathrm{CH}_{3}\right)_{3} \mathrm{~N}$ & $85.4 \pm 4.0^{73}$ & 80.2 \\
\hline $\mathrm{K}^{+}-\left(1-\mathrm{CH}_{3}\right.$-pyrazole $)$ & $94.0 \pm 4.0^{74}$ & 96.5 \\
\hline $\mathrm{K}^{+}$-pyrimidine & $69.0 \pm 4.0^{66}$ & 76.3 \\
\hline $\mathrm{Rb}^{+}-\mathrm{NH}_{3}$ & $75.1^{75}$ & 69.4 \\
\hline$\left(\mathrm{NH}_{3}\right) \mathrm{Rb}^{+}-\mathrm{NH}_{3}$ & $64.7^{75}$ & 57.5 \\
\hline $\mathrm{Rb}^{+}-\mathrm{CH}_{3} \mathrm{CN}$ & $86.6 \pm 1.0^{67}$ & 93.6 \\
\hline$\left(\mathrm{CH}_{3} \mathrm{CN}\right) \mathrm{Rb}^{+}-\mathrm{CH}_{3} \mathrm{CN}$ & $77.6 \pm 1.1^{67}$ & 77.1 \\
\hline$\left(\mathrm{H}_{2} \mathrm{O}\right) \mathrm{Rb}^{+}-\mathrm{H}_{2} \mathrm{O}$ & $57.8 \pm 4.0^{70}$ & 54.2 \\
\hline $\mathrm{Cs}^{+}-\left(\mathrm{CH}_{3} \mathrm{CN}\right)$ & $79.7 \pm 1.0^{67}$ & 86.2 \\
\hline$\left(\mathrm{CH}_{3} \mathrm{CN}\right) \mathrm{Cs}^{+}-\mathrm{CH}_{3} \mathrm{CN}$ & $71.3 \pm 1.0^{67}$ & 71.8 \\
\hline
\end{tabular}

TABLE I. Experimental and calculated gas phase bond dissociation $\Delta H_{0}$ of selected complexes with an uncertainty not greater than $4.0 \mathrm{~kJ} / \mathrm{mol}$.

at the DLPNO-CCSD(T)/aug-cc-p(wC)VTZ(-PP) level. The detailed results are shown in Table $\mathrm{S} 1$ (in the supplementary material). The calculations reveal that the MUE of $\omega \mathrm{B} 97 \mathrm{xD} / \mathrm{aug}-\mathrm{cc}-\mathrm{pVTZ}(-\mathrm{PP})$ and $\mathrm{PBE} /$ aug-cc-pVDZ(-PP) optimized geometries with respect to the default $\omega \mathrm{B} 97 \mathrm{xD} / \mathrm{aug}$-cc-pVDZ(-PP) optimized geometries are 0.4 and $0.4 \mathrm{~kJ} / \mathrm{mol}$, respectively. Furthermore, to evaluate the effect of DLPNO approximation, single point calculations at the $\operatorname{CCSD}(\mathrm{T}) /$ aug-cc-p(wC)VTZ(-PP) method have been performed. The MUE of $0.45 \mathrm{~kJ} / \mathrm{mol}$ between the DLPNO$\operatorname{CCSD}(\mathrm{T})$ and $\operatorname{CCSD}(\mathrm{T})$ methods indicates the reliability of DLPNO approximation.

\section{B. Bond dissociation energies of $M^{+}-L$}

We have collected a large number of systems including $\mathrm{Li}^{+}$, $\mathrm{Na}^{+}, \mathrm{K}^{+}, \mathrm{Rb}^{+}$, and $\mathrm{Cs}^{+}$ions binding various types of organic and inorganic ligands, including amino acids. For a number of species, the literature reports several experimental values along with a wide range of uncertainties. First, for each molecule, an average $\Delta H_{0}$ has been obtained by averaging all available experimental numbers. Second, the experimental uncertainties for each averaged value have been calculated in the following way. By combination of 


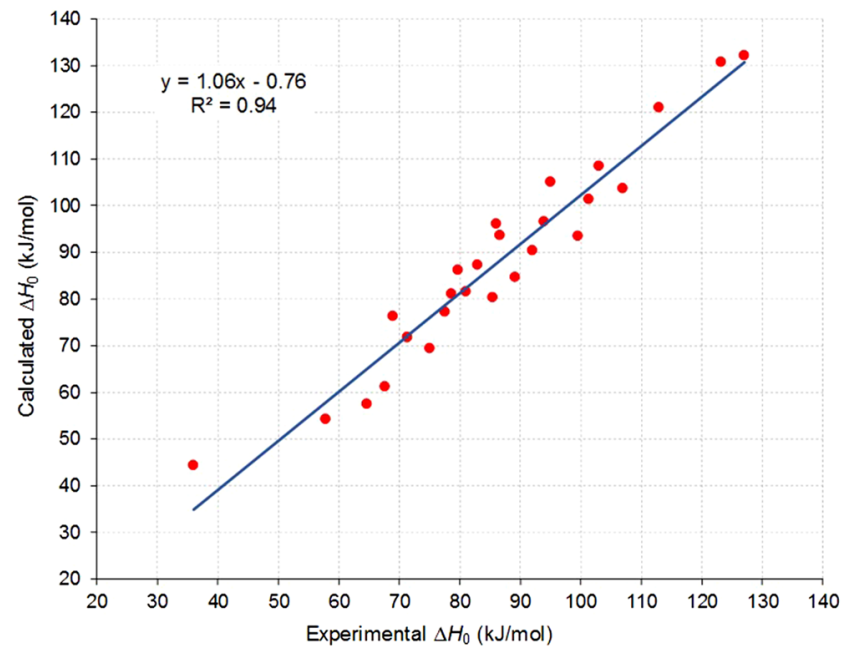

FIG. 1. Correlation between experimental and calculated DLPNO-CCSD(T)/CBS alkali metal cations-ligands dissociation enthalpies at $0 \mathrm{~K}\left(\Delta H_{0}\right)$. individual experimental values with corresponding uncertainties, the highest and the lowest possible numbers were obtained. Thereafter, the positive and negative deviations were calculated as a difference between the average enthalpy and the highest and lowest possible values, correspondingly.

\section{Lithium ion}

The average experimental $\mathrm{Li}^{+}-\mathrm{L}$ bond dissociation $\Delta H_{0}$ with error bars along with their DLPNO-CCSD(T) counterparts are shown in Fig. 2. The majority of calculated dissociation $\Delta H_{0}$ values have been found to be within the experimental error bars, indicating strong correlation between predicted and experimentally measured $\Delta H_{0}$. The overall MUE and MSE for $\mathrm{Li}^{+}-\mathrm{L}$ are 6.8 and $0.6 \mathrm{~kJ} / \mathrm{mol}$. The positive MSE indicates that theoretical values are generally overestimated. An examination identified only three exceptions as discussed herein. Thus, for the $\mathrm{Li}^{+}-\mathrm{HCO}_{2} \mathrm{CH}_{3}$ complex, predicted dissociation $\Delta H_{0}$ was found to be $189.2 \mathrm{~kJ} / \mathrm{mol}$ which is $18.1 \mathrm{~kJ} / \mathrm{mol}$ above the experimental value and out of an uncertainty bar. ${ }^{63,65,73,83}$ Similarly, $\mathrm{Li}^{+}-\mathrm{C}_{2} \mathrm{H}_{5} \mathrm{COOH}$ bond dissociation $\Delta H_{0}$ of $180.4 \mathrm{~kJ} / \mathrm{mol}$ is above the average of the two
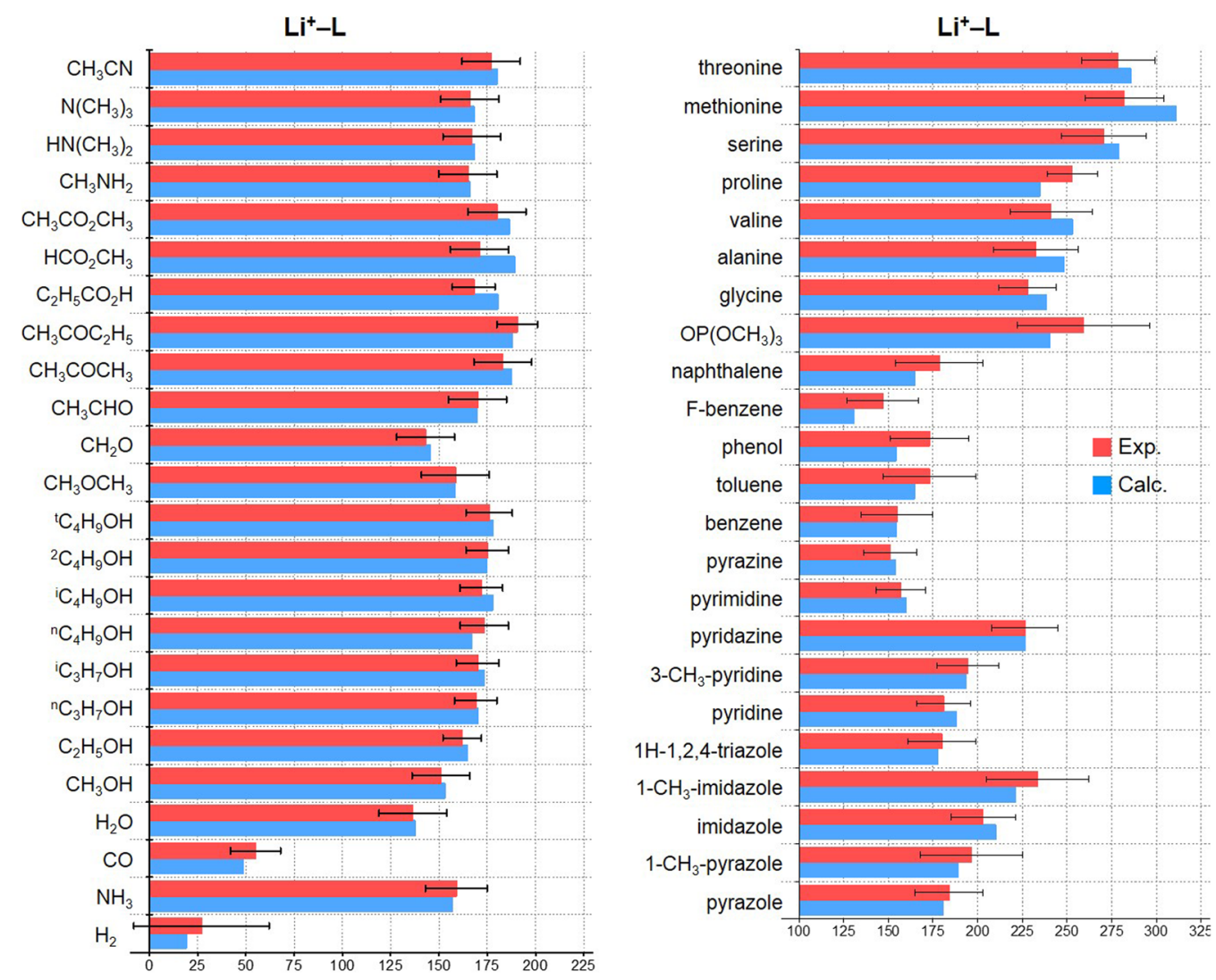

FIG. 2. Experimental and DLPNO-CCSD(T) bond dissociation $\Delta H_{0} \mathrm{~S}$ of $47 \mathrm{Li}^{+}-\mathrm{L}$ complexes in $\mathrm{kJ} / \mathrm{mol}$. 
available experimental numbers $\left(165.0 \pm 6.0^{25}\right.$ and $\left.168.0 \pm 11.0^{63-65}\right)$ and $1.4 \mathrm{~kJ} / \mathrm{mol}$ above the error bar. The DLPNO-CCSD(T) calculations also predict the $\mathrm{Li}^{+}$-Proline bond dissociation $\Delta H_{0}$ to be $234.8 \mathrm{~kJ} / \mathrm{mol}$ which is $18.2 \mathrm{~kJ} / \mathrm{mol}$ below an average of the two experimental values of $255.0 \pm 7.0^{84}$ and $253.0 \pm 14.0 \mathrm{~kJ} / \mathrm{mol}{ }^{85}$ As the calculated number is $4.2 \mathrm{~kJ} / \mathrm{mol}$ out of the uncertainty bar, we expect that another re-examination of the experimental data would be of interest.

Furthermore, we performed a detailed comparison of the calculated $\Delta H_{0}$ and their experimental counterparts for some selected species with largest error bars (Table S3 in the supplementary material for details). Thus, an experimental uncertainty for $\mathrm{Li}^{+}-\mathrm{H}_{2}$ of $35.0 \mathrm{~kJ} / \mathrm{mol}$ results in formal experimental $\Delta H_{0}$ ranging from -8.0 to $62.0 \mathrm{~kJ} / \mathrm{mol}^{86}$ Predicted $\Delta H_{0}$ for $\mathrm{Li}^{+}-\mathrm{H}_{2}$ dissociation amounts to $19.0 \mathrm{~kJ} / \mathrm{mol}$, which is reasonably close to experimentally derived $\Delta H_{0}$ of $27.0 \mathrm{~kJ} / \mathrm{mol}$. Hence, despite large experimental uncertainty tabulated in Ref. 86 for $\mathrm{Li}^{+}-\mathrm{H}_{2}, \Delta H_{0}$ value turned out to be accurate. The experimental $\mathrm{Li}^{+}-{ }^{\mathrm{n}} \mathrm{C}_{4} \mathrm{H}_{9} \mathrm{OH}$ bond dissociation $\Delta H_{0}$ is presented by four separate measurements: $178.0 \pm$ $8.0,{ }^{87} 169.0 \pm 8.0,{ }^{88} 177.0 \pm 8.0,{ }^{88}$ and $173.0 \pm 11.0 \mathrm{~kJ} / \mathrm{mol} .{ }^{63,65,83}$ The DLPNO-CCSD $(\mathrm{T})$ predicts $\Delta H_{0}$ of $166.8 \mathrm{~kJ} / \mathrm{mol}$, which suggests the second experimental measurement to be the most accurate. Two separate $\Delta H^{0}$ measurements of $207.0 \pm 18.0^{74}$ and $179.0 \pm 11.0^{63,65,83} \mathrm{~kJ} / \mathrm{mol}$ are reported for $\mathrm{Li}^{+}-\left(1-\mathrm{CH}_{3}-\right.$ pyrazole) resulting in overall uncertainty interval of $57.0 \mathrm{~kJ} / \mathrm{mol}$. The calculated value is $188.9 \mathrm{~kJ} / \mathrm{mol}$, which is $7.6 \mathrm{~kJ} / \mathrm{mol}$ below the average of the two experimental quantities (Fig. 2, Table S3). The $\mathrm{Li}^{+}$affinity to imidazole has been measured in two separate experiments resulting in $\Delta H_{0}$ of $211.0 \pm 10.0^{89}$ and $195.0 \pm 10.0 \mathrm{~kJ} / \mathrm{mol}^{63-65}$ The DLPNO-CCSD(T) prediction of $210.1 \mathrm{~kJ} / \mathrm{mol}$ supports the former measurement. Similarly, out of two independent $\Delta H_{0}$ measurements of $242.0 \pm 20.0^{74}$ and $216.0 \pm 11.0^{64} \mathrm{~kJ} / \mathrm{mol}$ reported for $\mathrm{Li}^{+}-\left(1-\mathrm{CH}_{3}\right.$-imidazole $)$, our calculated value of $221.2 \mathrm{~kJ} / \mathrm{mol}$ prefers the latter experimental number. We predict $\mathrm{Li}^{+}-(1 \mathrm{H}-1,2,4$-triazole $)$ bond dissociation $\Delta H_{0}$ of $177.7 \mathrm{~kJ} / \mathrm{mol}$ supporting the lowest of the two available experimental measurements of $191.0 \pm 8.0^{89}$ and $172.0 \pm 11.0 \mathrm{~kJ} / \mathrm{mol}^{63,65,83}$ DLPNO-CCSD(T) $\Delta H_{0}$ of $164.8 \mathrm{~kJ} / \mathrm{mol}$ obtained for $\mathrm{Li}^{+}$-toluene dissociation agrees well with experimentally measured value of 158.0 $\pm 11.0 \mathrm{~kJ} / \mathrm{mol}$ of Yanez and co-workers ${ }^{90}$ Whereas, other available experimental $\Delta H_{0}$ of $183.0 \pm 16.0^{91} \mathrm{~kJ} / \mathrm{mol}$ is apparently too high. Two experimental dissociation $\Delta H_{0}$ s for $\mathrm{Li}^{+}$-phenol are 179.0 $\pm 16.0^{92}$ and $162.0 \pm 11.0 \mathrm{~kJ} / \mathrm{mol},{ }^{63,65}$ which are considerably larger than our predicted value of $154.3 \mathrm{~kJ} / \mathrm{mol}$. The calculated dissociation $\Delta H_{0}$ of $130.6 \mathrm{~kJ} / \mathrm{mol}$ for $\mathrm{Li}^{+}-(\mathrm{F}-$ benzene) complex indicates that the experimental value of $147.0 \pm 20.0 \mathrm{~kJ} / \mathrm{mol}^{93}$ might be overestimated. Calculated $\Delta H_{0}$ dissociation for $\mathrm{Li}^{+}$-naphthalene of $165.1 \mathrm{~kJ} / \mathrm{mol}$ is in good agreement with the experimental value of $165.0 \pm 11.0^{90} \mathrm{~kJ} / \mathrm{mol}$, while other experimental $\Delta H_{0}$ of 187.0 $\pm 16.0^{94} \mathrm{~kJ} / \mathrm{mol}$ is apparently too high. A significant disagreement has been detected between two available experimental $\mathrm{Li}^{+}-$ $\mathrm{OP}\left(\mathrm{OCH}_{3}\right)_{3}$ bond dissociation $\Delta H_{0}$ s of $281.0 \pm 15.0^{95}$ and 233.0 $\pm 11.0 \mathrm{~kJ} / \mathrm{mol}^{64}$ Our predicted value of $240.7 \mathrm{~kJ} / \mathrm{mol}$ supports the latter measurements and indicates the former to be too high. The dissociation $\Delta H_{0}$ of $238.6 \mathrm{~kJ} / \mathrm{mol}$ calculated by the DLPNOCCDS(T) method for the $\mathrm{Li}^{+}$-glycine complex is significantly larger than any of the three available experimental measurements: 220.0 $\pm 8.0,{ }^{25} 224.0 \pm 10.0,{ }^{96}$ and $230.0 \pm 14.0 \mathrm{~kJ} / \mathrm{mol}^{85}$ However, the last one reported by Feng et al. is more close to our predicted value. For the $\mathrm{Li}^{+}$-alanine complex, our calculated bond dissociation $\Delta H_{0}$ of $248.2 \mathrm{~kJ} / \mathrm{mol}$ practically matches the larger of the two reported experimental values of $229.0 \pm 20.0^{97}$ and $239.0 \pm 17.0 \mathrm{~kJ} / \mathrm{mol} .^{85}$ Similarly, $\mathrm{Li}^{+}$-valine DLPNO-CCSD(T) $\Delta H_{0}$ of $253.1 \mathrm{~kJ} / \mathrm{mol}$ prefers the value of $247.0 \pm 17.0 \mathrm{~kJ} / \mathrm{mol}$ measured by Feng et al. ${ }^{85}$ over another experimental value of $238.0 \pm 20.0 \mathrm{~kJ} / \mathrm{mol}{ }^{97}$ The $\mathrm{Li}^{+}$-serine bond dissociation $\Delta H_{0}$ of $281.0 \pm 13.0 \mathrm{~kJ} / \mathrm{mol}$ measured by Armentrout and co-workers ${ }^{98}$ turned out to be reasonably close to our predicted value of $279.0 \mathrm{~kJ} / \mathrm{mol}$. Another experimental $\Delta H_{0}$ of 261.0 $\pm 14.0 \mathrm{~kJ} / \mathrm{mol}$ is apparently too low. ${ }^{85}$ Predicted dissociation $\Delta H_{0}$ of $311.0 \mathrm{~kJ} / \mathrm{mol}$ for $\mathrm{Li}^{+}$-methionine agrees well with the value of $292.0 \pm 12.0^{99} \mathrm{~kJ} / \mathrm{mol}$ indicating another experimental value of 274.0 $\pm 14.0 \mathrm{~kJ} / \mathrm{mol}^{85}$ to be slightly underestimated. Finally, for the $\mathrm{Li}^{+}-$ threonine complex, we predict dissociation $\Delta H_{0}$ of $285.6 \mathrm{~kJ} / \mathrm{mol}$ which is close to the highest of the two available experimental data: $285.0 \pm 14.0^{98}$ and $272.0 \pm 14.0 \mathrm{~kJ} / \mathrm{mol}^{8}$

\section{Sodium ion}

In general, DLPNO-CCSD $(\mathrm{T})$ predicted $\mathrm{Na}^{+}$-ligand noncovalent interaction energies are in good agreement with the experimental numbers as most of the calculated values are within the error bars; see Fig. 3. For $\mathrm{Na}^{+}-\mathrm{L}$, the overall MUE and MSE are 6.8 and $0.6 \mathrm{~kJ} / \mathrm{mol}$. The positive MSE indicates that theoretical values are relatively higher than experimental measurements. A few systems having significant inconsistency between calculated and experimental dissociation $\Delta H_{0}$ (Fig. 3, Table S4) shall be discussed in brief separately. For $\mathrm{Na}^{+}-\mathrm{CH}_{3} \mathrm{CHO}$, our predicted value of $121.0 \mathrm{~kJ} / \mathrm{mol}$ is $5.0 \mathrm{~kJ}$ larger than the highest possible experimental value of $113.0 \pm 3.0 \mathrm{~kJ} / \mathrm{mol}{ }^{100}$ Similar discrepancy has been revealed for $\mathrm{Na}^{+}-\mathrm{CH}_{3} \mathrm{CO}_{2} \mathrm{CH}_{3}$ where the experimental $\Delta H_{0}$ of $123.0 \pm 3.0^{62} \mathrm{~kJ} / \mathrm{mol}$ looks underestimated with respect to our predicted value of $130.8 \mathrm{~kJ} / \mathrm{mol}$.

Even if calculated $\Delta H_{0}$ values strongly correlate with the average experimental values, some individual measurements show significant deviations and inconsistencies resulting in wide error bars for some species; see Table S3. Alike the previous discussion for the $\mathrm{Li}^{+}-\mathrm{L}$ systems, we have compared the calculated $\Delta H_{0}$ with available individual experimental counterparts for $\mathrm{Na}^{+}-\mathrm{L}$ complexes. Predicted $\mathrm{Na}^{+}-\mathrm{CO}$ bond dissociation $\Delta H_{0}$ of $29.1 \mathrm{~kJ} / \mathrm{mol}$ is in good agreement with the experimental value of $32.0 \pm 8.0 \mathrm{~kJ} / \mathrm{mol}$ reported by Armentrout and co-workers. ${ }^{60}$ Other experimental value of $55.0 \mathrm{~kJ} / \mathrm{mol}$ measured by Castleman et al. is apparently too high. ${ }^{101}$ For $\mathrm{Na}^{+}-\mathrm{CH}_{3} \mathrm{OH}$, all experimental dissociation $\Delta H_{0}$ values are ranging from 86.0 to $111.0 \mathrm{~kJ} / \mathrm{mol}$. $^{62,102-105}$ Calculated $\Delta H_{0}$ of $104.8 \mathrm{~kJ} / \mathrm{mol}$ suggests the experimental value of $110.0 \pm 1.0 \mathrm{~kJ} / \mathrm{mol}$ obtained by Castleman and co-workers to be more accurate over other four reports. ${ }^{104}$ Our predicted $\Delta H_{0}$ of $113.7 \mathrm{~kJ} / \mathrm{mol}$ for $\mathrm{Na}^{+}-\mathrm{C}_{2} \mathrm{H}_{5} \mathrm{OH}$ supports strongly the value of $110.0 \pm 6.0 \mathrm{~kJ} / \mathrm{mol}$ measured by Amicangelo and Armentrout. ${ }^{106}$ Other experimental values $102.0 \pm 4.0^{102}$ and $106.0 \pm 3.0^{62} \mathrm{~kJ} / \mathrm{mol}$ available in the literature are probably less accurate. For $\mathrm{Na}^{+}-{ }^{n} \mathrm{C}_{3} \mathrm{H}_{7} \mathrm{OH}$, the computed $\Delta H_{0}$ of $118.0 \mathrm{~kJ} / \mathrm{mol}$ is in favor of the experimental number of $114.0 \pm 6.0 \mathrm{~kJ} / \mathrm{mol}$ obtained by Amicangelo and Armentrout. ${ }^{106}$ The DLPNO-CCSD(T) results in 120.5 and $116.1 \mathrm{~kJ} / \mathrm{mol}$ for $\mathrm{Na}^{+}{ }^{+}{ }^{\mathrm{n}} \mathrm{C}_{4} \mathrm{H}_{9} \mathrm{OH}$ and $\mathrm{Na}^{+}{ }_{-}{ }^{\mathrm{i}} \mathrm{C}_{4} \mathrm{H}_{9} \mathrm{OH}$ bond dissociation $\Delta H_{0}$. Even if both values are close to the identical number of $116.0 \pm 6.0 \mathrm{~kJ} / \mathrm{mol}$ measured by Amicangelo and 


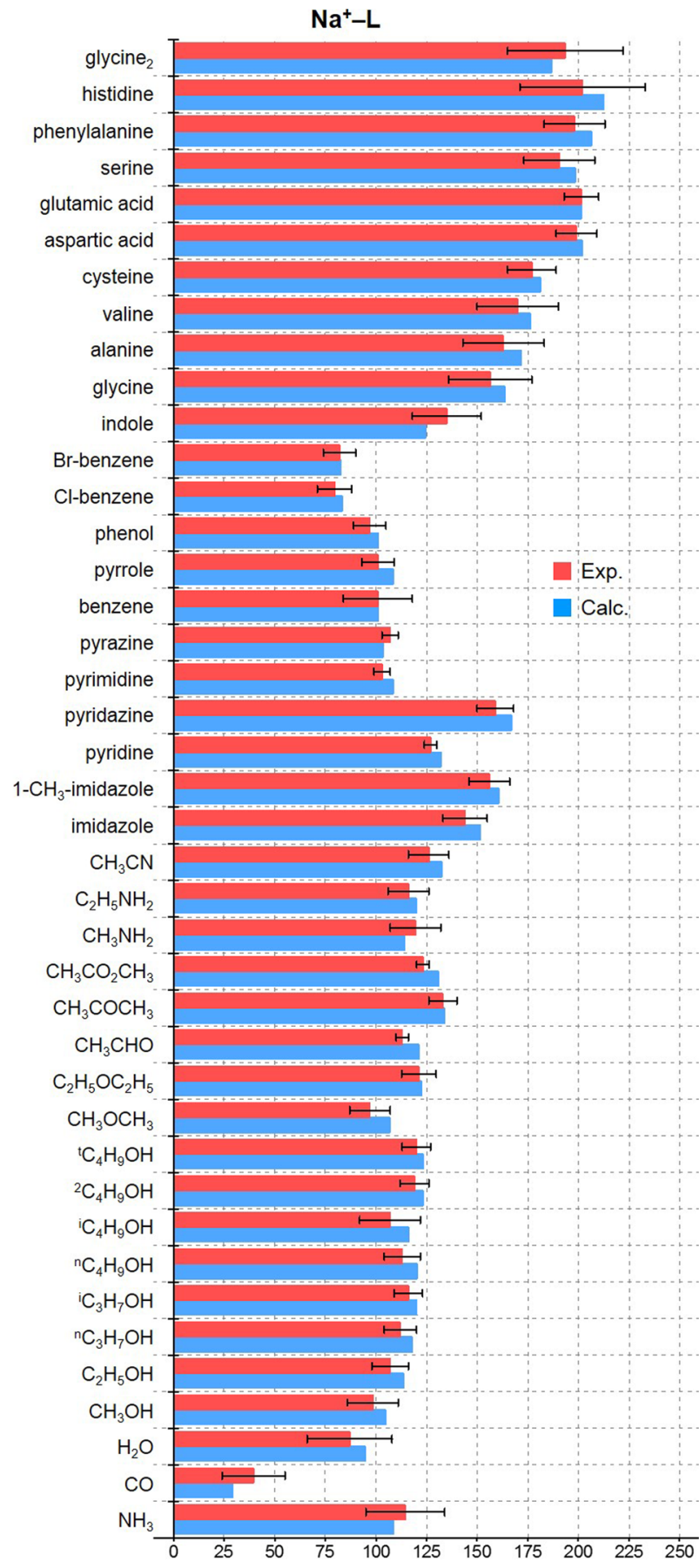

FIG. 3. Experimental and DLPNO-CCSD(T) bond dissociation $\Delta H_{0} \mathrm{~S}$ of $41 \mathrm{Na}^{+}-\mathrm{L}$ complexes in $\mathrm{kJ} / \mathrm{mol}$.

Armentrout ${ }^{106}$ for $\mathrm{Na}^{+}-{ }^{\mathrm{n}} \mathrm{C}_{4} \mathrm{H}_{9} \mathrm{OH}$ and $\mathrm{Na}^{+}-{ }^{\mathrm{i}} \mathrm{C}_{4} \mathrm{H}_{9} \mathrm{OH}$, the relative difference of 4.4 between the two $\Delta H_{0} \mathrm{~s}$ is not reproduced in the experiment. $\mathrm{Na}^{+}-{ }^{\mathrm{n}} \mathrm{C}_{4} \mathrm{H}_{9} \mathrm{OH}$ and $\mathrm{Na}^{+}-{ }^{\mathrm{i}} \mathrm{C}_{4} \mathrm{H}_{9} \mathrm{OH}$ bond dissociation $\Delta H_{0}$ s of $110.0 \pm 3.0$ and $111.0 \pm 3.0 \mathrm{~kJ} / \mathrm{mol}$ reported by
McMahon and Ohanessian ${ }^{62}$ incorrectly describe the relative bond strengths. Only $\Delta H_{0}$ of $109.0 \pm 5.0$ and $105.0 \pm 6.0 \mathrm{~kJ} / \mathrm{mol}$ measured by the same group of Armentrout at the very first report ${ }^{102}$ reproduced stronger $\mathrm{Na}^{+}$-ligand bonding in $\mathrm{Na}^{+}-{ }^{n} \mathrm{C}_{4} \mathrm{H}_{9} \mathrm{OH}$ comparing to that in $\mathrm{Na}^{+}-{ }^{\mathrm{i}} \mathrm{C}_{4} \mathrm{H}_{9} \mathrm{OH}$. In the case of $\mathrm{Na}^{+}-\mathrm{CH}_{3} \mathrm{OCH}_{3}$, the calculated value of $106.7 \mathrm{~kJ} / \mathrm{mol}$ is in good agreement with the experimental measurement of $101.0 \pm 6.0^{103} \mathrm{~kJ} / \mathrm{mol}$, while the other two experimental values of $92.0 \pm 5.0^{107}$ and $100.0 \pm 3.0^{62} \mathrm{~kJ} / \mathrm{mol}$ are somewhat low. Predicted dissociation $\Delta H_{0}$ of $\mathrm{Na}^{+}-\mathrm{CH}_{3} \mathrm{NH}_{2}$ of $114.2 \mathrm{~kJ} / \mathrm{mol}$ supports the threshold collision-induced dissociation experiment value of $113.0 \pm 6.0 \mathrm{~kJ} / \mathrm{mol}$ reported by El Aribi et al. ${ }^{108}$ Other two available experimental measurements of $132.0^{104}$ and $108.0 \pm 1.0^{105} \mathrm{~kJ} / \mathrm{mol}$ are somewhat larger and smaller, respectively. For $\mathrm{Na}^{+}$-indole, experimental bond dissociation energy of $138.0 \pm 14.0 \mathrm{~kJ} / \mathrm{mol}^{109}$ is overestimated compared to the DLPNO-CCSD $(\mathrm{T})$ predicted value of $124.4 \mathrm{~kJ} / \mathrm{mol}$, while the other experimental number $121.0 \pm 3.0 \mathrm{~kJ} / \mathrm{mol}^{110}$ is closer to our prediction. Similarly, for the $\mathrm{Na}^{+}-\mathrm{Cl}$-benzene complex, the two independent experimental dissociation $\Delta H_{0}$ s of $74.0 \pm 3.0^{111}$ and $80.0 \pm 8.0^{62} \mathrm{~kJ} / \mathrm{mol}$ are available, whereas the latter is relatively more supported by our prediction of $83.5 \mathrm{~kJ} / \mathrm{mol}$. For $\mathrm{Na}^{+}-$ glycine, the calculated $\Delta H_{0}$ of $163.8 \mathrm{~kJ} / \mathrm{mol}$ suggests the that the most accurate experimental value is $164.0 \pm 6.0 \mathrm{~kJ} / \mathrm{mol}{ }^{112}$ Three experimental $\Delta H_{0}$ s reported in the literature for $\mathrm{Na}^{+}$-cysteine are $177.0 \pm 5.0,{ }^{113} 177.0 \pm 12.0,{ }^{114}$ and $174.0 \pm 8.0 \mathrm{~kJ} / \mathrm{mol} .{ }^{115}$ The first two values are in good agreement with the DLPNO$\operatorname{CCSD}(\mathrm{T})$ value of $181.1 \mathrm{~kJ} / \mathrm{mol}$. The predicted dissociation $\Delta H_{0}$ of $198.4 \mathrm{~kJ} / \mathrm{mol}$ for $\mathrm{Na}^{+}$-serine supports the number of 200.0 $\pm 8.0^{98} \mathrm{~kJ} / \mathrm{mol}$ by Armentrout and co-workers in favor of other reported values of $185.0 \pm 12.0 \mathrm{~kJ} / \mathrm{mol}$ by Gapeev and Dunbar $^{114}$ and $189.0 \pm 8.0 \mathrm{~kJ} / \mathrm{mol}$ by Wesdemiotis. ${ }^{115}$ Similarly, for $\mathrm{Na}^{+}$-phenylalanine, our predicted $\Delta H_{0}$ of $206.4 \mathrm{~kJ} / \mathrm{mol}$ supports the experimental value of $206.0 \pm 7.0 \mathrm{~kJ} / \mathrm{mol}^{116}$ over other two reports of $195.0 \pm 12.0^{114}$ and $196.0 \pm 8.0 \mathrm{~kJ} / \mathrm{mol}^{115}$ In the case of $\mathrm{Na}^{+}$-histidine, the dissociation $\Delta H_{0}$ is presented by four separate measurements: $222.0 \pm 11.0,{ }^{117} 184.0 \pm 12.0,{ }^{114} 217.0 \pm 8.0,{ }^{115}$ and $225.0 \pm 8.0 \mathrm{~kJ} / \mathrm{mol}^{118}$ The DLPNO-CCSD(T) predicted $\Delta H_{0}$ of $212.6 \mathrm{~kJ} / \mathrm{mol}$, insisting on the third experimental measurement by Wesdemiotis and co-workers, is within the uncertainty of the first value, while the fourth value is overestimated, and the second one is apparently too low. There are many experimental bond dissociation energies reported for $\mathrm{Na}^{+}$-glycene $2: 209.0 \pm 13.0,{ }^{119} 179.0 \pm 10.0,{ }^{120}$ $184.0 \pm 16.0,{ }^{121} 201.0 \pm 8.0,{ }^{122}$ and $175.0 \pm 10.0 \mathrm{~kJ} / \mathrm{mol}$. ${ }^{67}$ The DLPNO-CCSD(T) predicted value of $186.5 \mathrm{~kJ} / \mathrm{mol}$ is closest to $\Delta H_{0}$ of $184.0 \pm 16.0 \mathrm{~kJ} / \mathrm{mol}$ reported by Feng et al. ${ }^{121}$

\section{Potassium ion}

For all but 6 species, predicted $\mathrm{K}^{+}-\mathrm{L}$ bond dissociation $\Delta H_{0} \mathrm{~s}$ are within experimental error bars suggesting a strong correlation between calculated and experimental values; see Fig. 4 (Table S5). The MUE for $\mathrm{Rb}^{+}-\mathrm{L}$ is $4.9 \mathrm{~kJ} / \mathrm{mol}$, and the positive MSE of $0.3 \mathrm{~kJ} / \mathrm{mol}$ indicates the theoretical $\Delta H_{0}$ values are in general higher than experimental findings. The discrepancies have been found for $\mathrm{K}^{+}-\mathrm{CH}_{3} \mathrm{OH}, \mathrm{K}^{+}-\mathrm{CH}_{3} \mathrm{COC}_{2} \mathrm{H}_{5}, \mathrm{~K}^{+}-\mathrm{C}_{2} \mathrm{H}_{5} \mathrm{COOH}, \mathrm{K}^{+}$-pyrazole, $\mathrm{K}^{+}$-pyridine and $\mathrm{K}^{+}$-pyrimidine. The single experimental value available for $\mathrm{K}^{+}-\mathrm{CH}_{3} \mathrm{OH} \Delta H_{0}$ of $90.8 \mathrm{~kJ} / \mathrm{mol}^{123}$ is $13.4 \mathrm{~kJ} / \mathrm{mol}$ higher than the DLPNO-CCSD $(\mathrm{T})$ predicted value of $77.4 \mathrm{~kJ} / \mathrm{mol}$. In contrast, for $\mathrm{K}^{+}-\mathrm{CH}_{3} \mathrm{COC}_{2} \mathrm{H}_{5}$, the predicted dissociation $\Delta H_{0}$ 


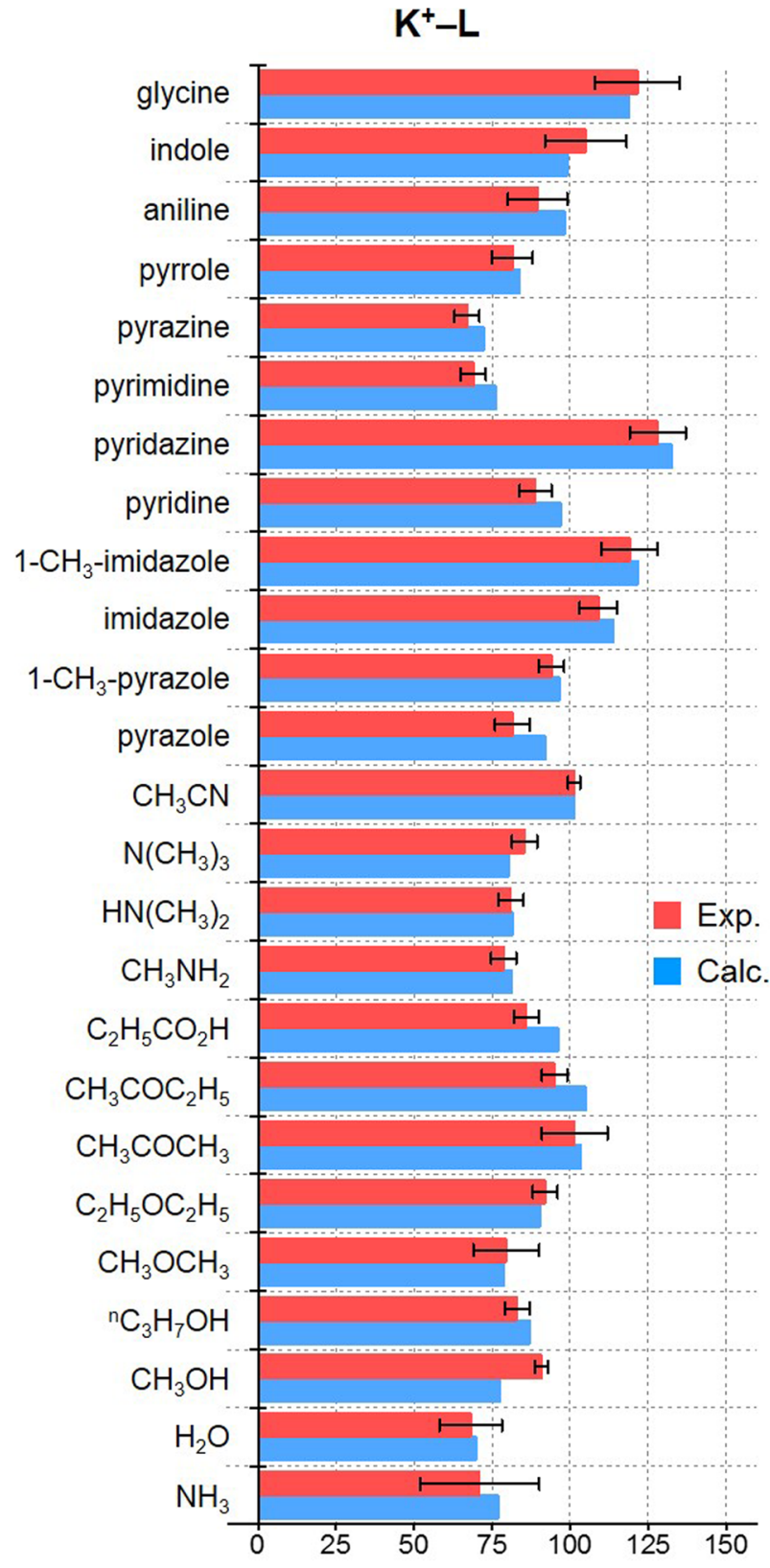

FIG. 4. Experimental and DLPNO-CCSD(T) bond dissociation $\Delta H_{0} \mathrm{~S}$ of $25 \mathrm{~K}^{+}-\mathrm{L}$ complexes in $\mathrm{kJ} / \mathrm{mol}$.

is $105.0 \mathrm{~kJ} / \mathrm{mol}$ which is larger than the experimental value by $10.0 \mathrm{~kJ} / \mathrm{mol}$ and $6.0 \mathrm{~kJ} / \mathrm{mol}$ upper bound than the error bar. ${ }^{68}$ Similarly, $\mathrm{K}^{+}-\mathrm{C}_{2} \mathrm{H}_{5} \mathrm{COOH} \Delta H_{0}$ of $86.0 \pm 4.0 \mathrm{~kJ} / \mathrm{mol}$ measured by Moision and Armentrout ${ }^{68}$ is lower than the predicted value of $96.1 \mathrm{~kJ} / \mathrm{mol}$. Calculated dissociation $\Delta H_{0}$ s of $\mathrm{K}^{+}$-pyrazole and $\mathrm{K}^{+}$-pyridine are 92.2 and $97.0 \mathrm{~kJ} / \mathrm{mol}$, respectively; those are higher than the respective experimental values by 10.7 and $8.1 \mathrm{~kJ} / \mathrm{mol}$ (Fig. 4, Table S5). ${ }^{66,69,74,124}$ For K ${ }^{+}$-pyrimidine, the experimental dissociation energy of $69.0 \pm 4.0^{66} \mathrm{~kJ} / \mathrm{mol}$ is in reasonable agreement with our predicted value of $76.3 \mathrm{~kJ} / \mathrm{mol}$.

Four individual complexes of $\mathrm{K}^{+}-\mathrm{L}$ for which individual experimental measurements are not consistent are discussed herein. For the $\mathrm{K}^{+}-\mathrm{CH}_{3} \mathrm{OCH}_{3}$ complex, our predicted bond dissociation $\Delta H_{0}$ of $78.8 \mathrm{~kJ} / \mathrm{mol}$ is in between two reported experimental values of $73.0 \pm 4.0^{125}$ and $86.0 \pm 4.0^{126} \mathrm{~kJ} / \mathrm{mol}$. Our predicted value of $92.2 \mathrm{~kJ} / \mathrm{mol}$ for $\mathrm{K}^{+}$-pyrazole supports the experimental number of $84.0 \pm 3.0 \mathrm{~kJ} / \mathrm{mol}$ measured by Huang and Rodgers ${ }^{74}$ and indicates the other reported value $80.0 \pm 4.0 \mathrm{~kJ} / \mathrm{mol}$ to be slightly underestimated. ${ }^{124}$ Similarly, $\mathrm{K}^{+}$-pyridine dissociation $\Delta H_{0}$ is represented by the two experimental values of $90.0 \pm 4.0^{66}$ and $87.7 \pm 4.0 \mathrm{~kJ} / \mathrm{mol}$. ${ }^{69}$ Our predicted $\Delta H_{0}$ of $97.0 \mathrm{~kJ} / \mathrm{mol}$ supports the former measurement. The DLPNO-CCSD(T) predicted value of $98.3 \mathrm{~kJ} / \mathrm{mol}$ for $\mathrm{K}^{+}$-aniline is higher than both the experimental measurements of $83.0 \pm 3.0^{127}$ and $95.0 \pm 4.0 \mathrm{~kJ} / \mathrm{mol}^{69}{ }^{6}$ However, the latter one is closer to our predicted $\Delta H_{0}$.

\section{Rubidium and cesium ions}

Finally, the DLPNO-CCSD(T) method has been utilized to rationalize the available experimental measurements for noncovalent bond dissociation in $\mathrm{Rb}^{+}$and $\mathrm{Cs}^{+}$complexes (see Fig. 5 and Table S5). The MUEs for $\mathrm{Rb}^{+}-\mathrm{L}$ and $\mathrm{Cs}^{+}-\mathrm{L}$ are 4.6 and $7.0 \mathrm{~kJ} / \mathrm{mol}$, and the respective MSEs are 0.0 and $3.7 \mathrm{~kJ} / \mathrm{mol}$. The positive MSEs in both cases indicate theoretical values are generally overestimated. In case of $\mathrm{Rb}^{+}-\mathrm{NH}_{3}$, our predicted dissociation $\Delta H_{0}$ of $69.4 \mathrm{~kJ} / \mathrm{mol}$ is a bit smaller than the experimental value of $75.1 \mathrm{~kJ} / \mathrm{mol}^{75} \mathrm{Sim}$ ilarly, for $\mathrm{Rb}^{+}-\mathrm{CH}_{3} \mathrm{CN}$, the experimental value of $86.6 \pm 1.0^{67}$ $\mathrm{kJ} / \mathrm{mol}$ looks slightly underestimated comparing to our predicted value of $93.6 \mathrm{~kJ} / \mathrm{mol}$. $\mathrm{Cs}^{+}-\mathrm{CH}_{3} \mathrm{CN}$ complex also shows the same trend where experimental value of $79.7 \pm 1.0^{67} \mathrm{~kJ} / \mathrm{mol}$ is smaller than the DLPNO-CCSD $(\mathrm{T})$ predicted value of $86.2 \mathrm{~kJ} / \mathrm{mol}$. However, in all cases, the discrepancy between the experimental and $\operatorname{DLPNO}-\operatorname{CCSD}(\mathrm{T})$ values is within $6.0 \mathrm{~kJ} / \mathrm{mol}$, indicating an

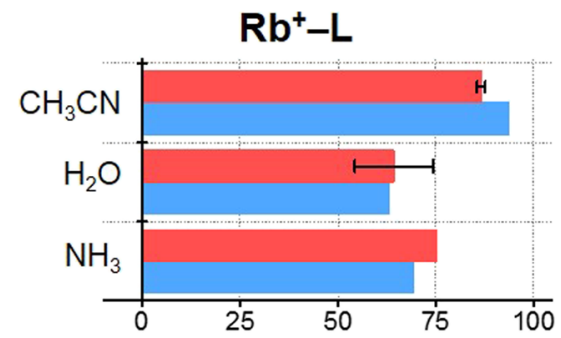

Exp.

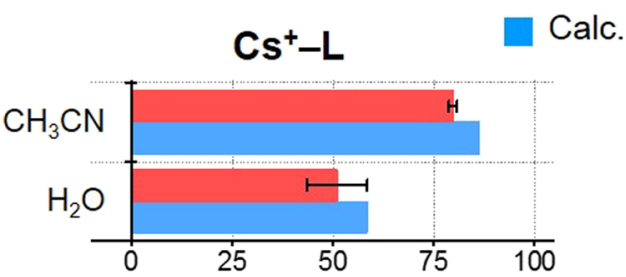

FIG. 5. Experimental and DLPNO-CCSD(T) bond dissociation $\Delta H_{0} S$ of $R b^{+}-L$ ( 3 complexes) and $\mathrm{Cs}^{+}-\mathrm{L}$ (2 complexes) in $\mathrm{kJ} / \mathrm{mol}$. 
(L) $\mathrm{Li}^{+}-\mathrm{L}$

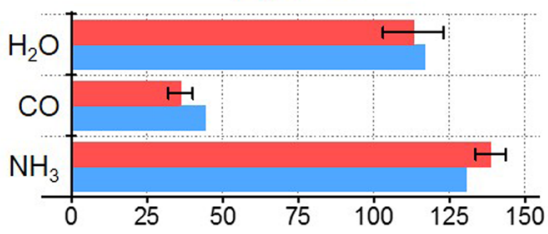

Exp.

Calc.

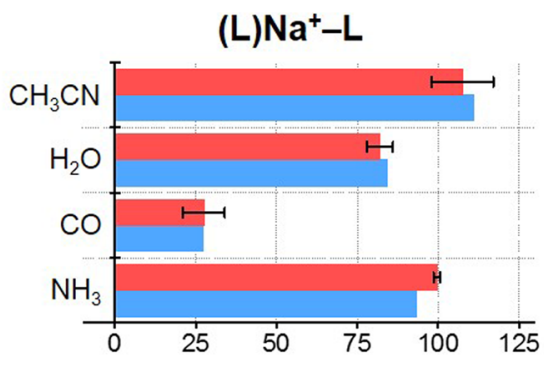

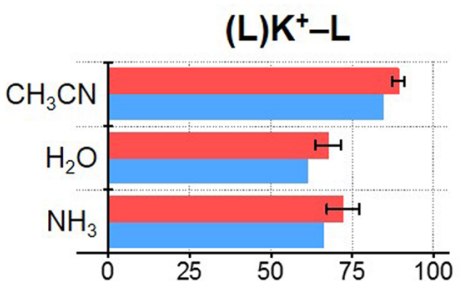
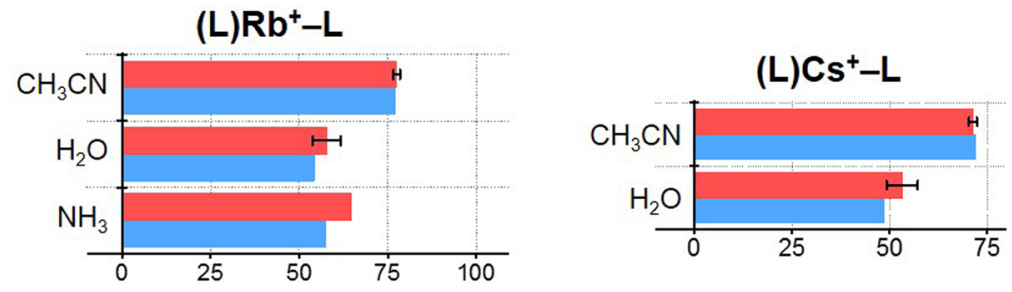

FIG. 6. Experimental and DLPNO-CCSD $(\mathrm{T})$ bond dissociation $\Delta H_{0}$ S of $15(\mathrm{~L}) \mathrm{M}^{+}-\mathrm{L}$ complexes in $\mathrm{kJ} / \mathrm{mol}$.

excellent performance of the DLPNO-CCSD $(\mathrm{T})$ method and/or good quality of the measurements. For the $\mathrm{Cs}^{+}-\mathrm{H}_{2} \mathrm{O}$ complex, the two $\Delta H_{0}$ experimental measurements of $54.4 \pm 4.0^{70}$ and $47.5 \pm 4.0^{128} \mathrm{~kJ} / \mathrm{mol}$ reported in the literature are in good agreement with our predicted value of $58.4 \mathrm{~kJ} / \mathrm{mol}$.

\section{Noncovalent bond dissociation energies of $(L) M^{+}-L$}

In this section, we focus on selected species with two ligands bound to the metal cation, (L) $\mathrm{M}^{+}-\mathrm{L}$ shown in Fig. 6 (refer to Table S6 in the supplementary material for more details). Similarly to previous results, DLPNO-CCSD $(\mathrm{T})$ predicted first ligand dissociation $\Delta H_{0}$ values agree reasonably well with the reported experimental measurements. The calculated MUEs for $(\mathrm{L}) \mathrm{M}^{+}-\mathrm{L}(\mathrm{M}=\mathrm{Li}$, $\mathrm{Na}, \mathrm{K}, \mathrm{Rb}$, and $\mathrm{Cs}$ ) are $6.6,3.1,5.7,3.8$, and $2.6 \mathrm{~kJ} / \mathrm{mol}$, and the respective MSEs are $1.4,-0.2,-5.7,-3.8$, and $-2.1 \mathrm{~kJ} / \mathrm{mol}$. All the negative values of MSE except for $(\mathrm{L}) \mathrm{Li}^{+}-\mathrm{L}$ indicate that theoretical values are mostly lower than those of the experiment. For the $\left(\mathrm{NH}_{3}\right) \mathrm{Li}^{+}-\mathrm{NH}_{3}$ complex, the dissociation $\Delta H_{0}$ of $130.7 \mathrm{~kJ} / \mathrm{mol}$ was predicted which is slightly lower than the available experimental value of $138.6 \pm 5.0 \mathrm{~kJ} / \mathrm{mol}$ reported by Castleman et al. ${ }^{61}$ In contrast, for $(\mathrm{CO}) \mathrm{Li}^{+}-\mathrm{CO}$, the experimental measurement of $36.0 \pm 4.0^{60} \mathrm{~kJ} / \mathrm{mol}$ turned out to be slightly lower comparing to DLPNO-CCSD(T) calculated $\Delta H_{0}$ of $44.3 \mathrm{~kJ} / \mathrm{mol}$. In the case of $\left(\mathrm{NH}_{3}\right) \mathrm{Na}^{+}-\mathrm{NH}_{3}$, our protocol provides the $\Delta H_{0}$ of $93.4 \mathrm{~kJ} / \mathrm{mol}$ which is $6.2 \mathrm{~kJ} / \mathrm{mol}$ smaller than experimental findings of $99.6 \pm 1.0 \mathrm{~kJ} / \mathrm{mol}$ and $5.2 \mathrm{~kJ} / \mathrm{mol}$ smaller than the error bar. ${ }^{61}$ The first $\mathrm{NH}_{3}$ dissociation $\Delta H_{0}$ of $\left(\mathrm{NH}_{3}\right) \mathrm{K}^{+}-\mathrm{NH}_{3}$ species is $72.2 \pm 5.0$ $\mathrm{kJ} / \mathrm{mol}$ as measured experimentally. ${ }^{75,129}$ This value is higher by 6.0 $\mathrm{kJ} / \mathrm{mol}$ than our predicted number of $66.2 \mathrm{~kJ} / \mathrm{mol}$. For $\left(\mathrm{NH}_{3}\right) \mathrm{Rb}^{+}-$ $\mathrm{NH}_{3}$, the experimental value of $64.7 \mathrm{~kJ} / \mathrm{mol}$ turned out to be $7.2 \mathrm{~kJ} / \mathrm{mol}$ larger comparing DLPNO-CCSD $(\mathrm{T})$ predicted value of $57.5 \mathrm{~kJ} / \mathrm{mol}^{75}$ In contrast, for $\left(\mathrm{CH}_{3} \mathrm{CN}\right) \mathrm{Rb}^{+}-\mathrm{CH}_{3} \mathrm{CN}$ our calculated $\Delta H_{0}$ of $77.1 \mathrm{~kJ} / \mathrm{mol}$ is strongly supported by the experimental value of $77.6 \pm 1.0 \mathrm{~kJ} / \mathrm{mol}$ measured by Davidson and Kebarle. ${ }^{67}$
As for some species, the experimental $\Delta H_{0}$ s are in disagreement with each other, and we applied the DLPNO-CCSD $(\mathrm{T})$ method to rationalize the measurements. Thus, for $\left(\mathrm{H}_{2} \mathrm{O}\right) \mathrm{Li}^{+}-\mathrm{H}_{2} \mathrm{O}$ species, the two separate experimental values of $113.0 \pm 10.0$ and $107.0 \pm 4.0 \mathrm{~kJ} / \mathrm{mol}$ have been reported by Rodgers and Armentrout $^{130}$ and Dzidic and Kebarle. ${ }^{70}$ Our calculated value of $116.7 \mathrm{~kJ} / \mathrm{mol}$ strongly supports the former measurement. Similarly, for $(\mathrm{CO}) \mathrm{Na}^{+}-\mathrm{CO}$ species, our predicted $\Delta H_{0}$ of $27.1 \mathrm{~kJ} / \mathrm{mol}$ is in good agreement with the experimental value of $24.0 \pm 3.0 \mathrm{~kJ} / \mathrm{mol}$, ${ }^{60}$ while the other measurements of $34.0 \mathrm{~kJ} / \mathrm{mol}$ is somewhat overestimated. ${ }^{101}$ Between two experimental dissociation $\Delta H_{0} \mathrm{~s}$ of $102.0 \pm 4.0^{67}$ and $109.0 \pm 8.0^{131} \mathrm{~kJ} / \mathrm{mol}$ for $\left(\mathrm{CH}_{3} \mathrm{CN}\right) \mathrm{Na}^{+}-\mathrm{CH}_{3} \mathrm{CN}$, our predicted value of $111.0 \mathrm{~kJ} / \mathrm{mol}$ indicates the second measurement to be more accurate over the first one.

\section{CONCLUSIONS}

We utilized the DLPNO-CCSD $(\mathrm{T})$ approach to evaluate the experimentally measured dissociation energies collected for alkali metal ions and a wide set of noncovalently bonded organic (olefins, $\mathrm{N}$ - and $\mathrm{O}$-donors, amino acids, etc. $)$ and inorganic ligands $\left(\mathrm{H}_{2}, \mathrm{H}_{2} \mathrm{O}\right.$, $\mathrm{H}_{2} \mathrm{~S}$, etc.). In general, good to excellent agreement has been found between predicted and experimental $H_{0}$-corrected energies has been found indicating a high degree of reliability for the data compilation of Rodgers and Armentrout, assembled by extracting values from different experimental papers. ${ }^{3}$ In the case of some inconsistent experimental data given for some species, we pointed to a number for which best agreement with DLPNO-CCSD(T) calculations has been achieved. Furthermore, we refined a few dissociation energies for which our predicted numbers turned out to be significantly different from their experimental counterparts. We suggest use of the DLPNO-CCSD $(\mathrm{T})$ derived thermochemical parameters for alkali metal reactions as reference values to train/validate force field and neural network methods, ${ }^{132-140}$ to be further applied in 
molecular dynamic simulations to unravel the mechanisms in biological systems and alkali-metal ion batteries. Finally, the DLPNO$\operatorname{CCSD}(\mathrm{T})$ reaction enthalpies can be further utilized for derivation of the gas phase heats of formation of alkali metal ion-ligand complexes following our recent study on silver compounds. ${ }^{141}$

\section{SUPPLEMENTARY MATERIAL}

See supplementary material for experimental and calculated dissociation $\Delta H_{0}$ in gas phase of all species studied in this report (shown in Table S1-S6), Cartesian coordinates (A), ZPE and enthalpic corrections, and DLPNO-CCSD $(\mathrm{T})$ energies with different basis sets of all species (tabulated in Table S7).

\section{ACKNOWLEDGMENTS}

The research reported in this publication was supported by funding from King Abdullah University of Science and Technology (KAUST). For computer time, this research used the resources of the Supercomputing Laboratory at King Abdullah University of Science and Technology (KAUST) in Thuwal, Saudi Arabia. Y.M. gratefully acknowledges support from the Government of the Russian Federation (Agreement No. 074-02-2018-286).

The authors declare no competing financial interest.

\section{REFERENCES}

${ }^{1}$ P. Hobza and K. Muller-Dethlefs, Non-Covalent Interactions: Theory and Experiment (Royal Society of Chemistry, 2009).

${ }^{2}$ K. Muller-Dethlefs and P. Hobza, Chem. Rev. 100, 143 (2000).

${ }^{3}$ M. T. Rodgers and P. B. Armentrout, Chem. Rev. 116, 5642 (2016).

${ }^{4}$ J. F. J. Cade, Med. J. Aust. 2, 349 (1949).

${ }^{5}$ M. Bauer, M. Adli, T. Bschor, M. Pilhatsch, A. Pfennig, J. Sasse, R. Schmid, and U. Lewitzka, Neuropsychobiology 62, 36 (2010).

${ }^{6}$ T. Bschor, B. Canata, B. Muller-Oerlinghausen, and M. Bauer, J. Affective Disord. 64, 261 (2001)

${ }^{7}$ R. C. Peatfield, J. R. Soc. Med. 74, 432 (1981).

${ }^{8}$ R. O. Bach, Med. Hypotheses 23, 157 (1987).

${ }^{9}$ J. C. Skou, Scand. J. Clin. Lab. Inv. 46, 11 (1986).

${ }^{10}$ J. N. Deng, J. Q. Guo, J. Li, M. Zeng, and Z. Yang, Mater. Lett. 234, 35 (2019).

${ }^{11}$ N. J. Birch, Chem. Rev. 99, 2659 (1999).

${ }^{12}$ N. Nitta, F. X. Wu, J. T. Lee, and G. Yushin, Mater. Today 18, 252 (2015).

${ }^{13} \mathrm{~J}$. M. Tarascon and M. Armand, Nature 414, 359 (2001).

${ }^{14}$ N. Yabuuchi, K. Kubota, M. Dahbi, and S. Komaba, Chem. Rev. 114, 11636 (2014).

${ }^{15}$ G. W. Gokel, L. J. Barbour, S. L. De Wall, and E. S. Meadows, Coord. Chem. Rev. 222, 127 (2001).

${ }^{16}$ J. C. Ma and D. A. Dougherty, Chem. Rev. 97, 1303 (1997).

${ }^{17}$ D. A. Dougherty, Science 271, 163 (1996).

${ }^{18}$ D. A. Dougherty, Acc. Chem. Res. 46, 885 (2013).

${ }^{19}$ A. J. Austin, M. J. Frisch, J. A. Montgomery, and G. A. Petersson, Theor. Chem. Acc. 107, 180 (2002).

${ }^{20}$ G. Bistoni, C. Riplinger, Y. Minenkov, L. Cavallo, A. A. Auer, and F. Neese, J. Chem. Theory Comput. 13, 3220 (2017).

${ }^{21}$ A. Schulz, B. J. Smith, and L. Radom, J. Phys. Chem. A 103, 7522 (1999).

${ }^{22}$ M. B. Sullivan, M. A. Iron, P. C. Redfern, J. M. L. Martin, L. A. Curtiss, and L. Radom, J. Phys. Chem. A 107, 5617 (2003).

${ }^{23}$ M. A. Iron, M. Oren, and J. M. L. Martin, Mol. Phys. 101, 1345 (2003).

${ }^{24}$ Y. Minenkov, G. Bistoni, C. Riplinger, A. A. Auer, F. Neese, and L. Cavallo, Phys. Chem. Chem. Phys. 19, 9374 (2017).

${ }^{25}$ M. T. Rodgers and P. B. Armentrout, Int. J. Mass Spectrom. 267, 167 (2007).
${ }^{26}$ T. Leininger, A. Nicklass, W. Kuchle, H. Stoll, M. Dolg, and A. Bergner, Chem. Phys. Lett. 255, 274 (1996).

${ }^{27}$ C. J. Cramer, Essentials of Computational Chemistry: Theories and Models, 2nd ed. (Wiley, 2005).

${ }^{28} \mathrm{~F}$. Jensen, Introduction to Computational Chemistry, 2nd ed. (Wiley, 2006).

${ }^{29}$ K. A. Peterson, D. Feller, and D. A. Dixon, Theor. Chem. Acc. 131, 1079 (2012).

${ }^{30}$ D. A. Dixon, D. Feller, and K. A. Peterson, Annual Reports in Computational Chemistry (Elsevier, 2012), pp. 1-28.

${ }^{31}$ D. Feller, K. A. Peterson, and D. A. Dixon, J. Chem. Phys. 129, 204105 (2008).

${ }^{32}$ K. Raghavachari, G. W. Trucks, J. A. Pople, and M. Headgordon, Chem. Phys. Lett. 157, 479 (1989).

${ }^{33}$ C. Riplinger, B. Sandhoefer, A. Hansen, and F. Neese, J. Chem. Phys. 139, 134101 (2013).

${ }^{34}$ C. Riplinger, P. Pinski, U. Becker, E. F. Valeev, and F. Neese, J. Chem. Phys. 144, 024109 (2016).

${ }^{35}$ C. Riplinger and F. Neese, J. Chem. Phys. 138, 034106 (2013).

${ }^{36}$ Y. Minenkov, V. V. Sliznev, and L. Cavallo, Inorg. Chem. 56, 1386 (2017).

${ }^{37}$ D. G. Liakos, M. Sparta, M. K. Kesharwani, J. M. L. Martin, and F. Neese, J. Chem. Theory Comput. 11, 1525 (2015).

${ }^{38}$ Y. Minenkov, H. Wang, Z. D. Wang, S. M. Sarathy, and L. Cavallo, J. Chem. Theory Comput. 13, 3537 (2017).

${ }^{39}$ Y. Minenkov, E. Chermak, and L. Cavallo, J. Chem. Theory Comput. 11, 4664 (2015).

${ }^{40}$ Y. Minenkov, E. Chermak, and L. Cavallo, J. Chem. Theory Comput. 12, 1542 (2016).

${ }^{41}$ J. D. Chai and M. Head-Gordon, Phys. Chem. Chem. Phys. 10, 6615 (2008).

${ }^{42}$ M. J. Frisch, G. W. Trucks, H. B. Schlegel, G. E. Scuseria, M. A. Robb, J. R. Cheeseman, G. Scalmani, V. Barone, B. Mennucci, G. A. Petersson, H. Nakatsuji, M. Caricato, X. Li, H. P. Hratchian, A. F. Izmaylov, J. Bloino, G. Zheng, J. L. Sonnenberg, M. Hada, M. Ehara, K. Toyota, R. Fukuda, J. Hasegawa, M. Ishida, T. Nakajima, Y. Honda, O. Kitao, H. Nakai, T. Vreven, J. A. Montgomery, Jr., J. E. Peralta, F. Ogliaro, M. Bearpark, J. J. Heyd, E. Brothers, K. N. Kudin, V. N. Staroverov, R. Kobayashi, J. Normand, K. Raghavachari, A. Rendell, J. C. Burant, S. S. Iyengar, J. Tomasi, M. Cossi, N. Rega, J. M. Millam, M. Klene, J. E. Knox, J. B. Cross, V. Bakken, C. Adamo, J. Jaramillo, R. Gomperts, R. E. Stratmann, O. Yazyev, A. J. Austin, R. Cammi, C. Pomelli, J. W. Ochterski, R. L. Martin, K. Morokuma, V. G. Zakrzewski, G. A. Voth, P. Salvador, J. J. Dannenberg, S. Dapprich, A. D. Daniels, Ö. Farkas, J. B. Foresman, J. V. Ortiz, J. Cioslowski, and D. J. Fox, Gaussian 09, Revision D.01, Gaussian, Inc., Wallingford, CT, 2013.

${ }^{43}$ S. E. Wheeler and K. N. Houk, J. Chem. Theory Comput. 6, 395 (2010).

${ }^{44}$ E. R. Johnson, I. D. Mackie, and G. A. DiLabio, J. Phys. Org. Chem. 22, 1127 (2009).

${ }^{45}$ E. R. Johnson, A. D. Becke, C. D. Sherrill, and G. A. DiLabio, J. Chem. Phys. 131, 034111 (2009).

${ }^{46}$ R. A. Kendall, T. H. Dunning, and R. J. Harrison, J. Chem. Phys. 96, 6796 (1992).

${ }^{47}$ B. P. Prascher, D. E. Woon, K. A. Peterson, T. H. Dunning, and A. K. Wilson, Theor. Chem. Acc. 128, 69 (2011).

${ }^{48}$ J. G. Hill and K. A. Peterson, J. Chem. Phys. 147, 244106 (2017).

${ }^{49}$ For basis sets repository see http://www.grant-hill.group.shef.ac.uk/ccrepo/\#.

${ }^{50}$ I. S. Lim, P. Schwerdtfeger, B. Metz, and H. Stoll, J. Chem. Phys. 122, 104103 (2005).

${ }^{51}$ F. Neese, Wiley Interdiscip. Rev.: Comput. Mol. Sci. 2, 73 (2012).

${ }^{52}$ Y. Guo, C. Riplinger, U. Becker, D. G. Liakos, Y. Minenkov, L. Cavallo, and F. Neese, J. Chem. Phys. 148, 011101 (2018).

${ }^{53}$ D. E. Woon and T. H. Dunning, J. Chem. Phys. 98, 1358 (1993).

${ }^{54}$ N. J. DeYonker, K. A. Peterson, and A. K. Wilson, J. Phys. Chem. A 111, 11383 (2007).

${ }^{55}$ K. A. Peterson, D. Figgen, E. Goll, H. Stoll, and M. Dolg, J. Chem. Phys. 119, 11113 (2003).

${ }^{56}$ I. S. Lim, P. Schwerdtfeger, T. Sohnel, and H. Stoll, J. Chem. Phys. 122, 134307 (2005).

${ }^{57}$ A. Halkier, T. Helgaker, P. Jorgensen, W. Klopper, H. Koch, J. Olsen, and A. K. Wilson, Chem. Phys. Lett. 286, 243 (1998). 
${ }^{58}$ A. Halkier, T. Helgaker, P. Jorgensen, W. Klopper, and J. Olsen, Chem. Phys. Lett. 302, 437 (1999).

${ }^{59}$ T. Helgaker, W. Klopper, H. Koch, and J. Noga, J. Chem. Phys. 106, 9639 (1997).

${ }^{60}$ D. Walter, M. R. Sievers, and P. B. Armentrout, Int. J. Mass Spectrom. 175, 93 (1998).

${ }^{61}$ A. W. Castleman, P. M. Holland, D. M. Lindsay, and K. I. Peterson, J. Am. Chem. Soc. 100, 6039 (1978).

${ }^{62}$ T. B. McMahon and G. Ohanessian, Chem. - Eur. J. 6, 2931 (2000).

${ }^{63}$ P. Burk, I. A. Koppel, I. Koppel, R. Kurg, J. F. Gal, P. C. Maria, M. Herreros, R. Notario, J. L. M. Abboud, F. Anvia, and R. W. Taft, J. Phys. Chem. A 104, 2824 (2000).

${ }^{64}$ C. Mayeux, P. Burk, J. F. Gal, I. Kaljurand, I. Koppel, I. Leito, and L. Sikk, J. Am. Soc. Mass Spectrom. 25, 1962 (2014).

${ }^{65}$ R. W. Taft, F. Anvia, J. F. Gal, S. Walsh, M. Capon, M. C. Holmes, K. Hosn, G. Oloumi, R. Vasanwala, and S. Yazdani, Pure Appl. Chem. 62, 17 (1990).

${ }^{66} \mathrm{R}$. Amunugama and M. T. Rodgers, Int. J. Mass Spectrom. 195, 439 (2000).

${ }^{67}$ W. R. Davidson and P. Kebarle, J. Am. Chem. Soc. 98, 6125 (1976).

${ }^{68}$ R. M. Moision and P. B. Armentrout, Phys. Chem. Chem. Phys. 6, 2588 (2004).

${ }^{69}$ W. R. Davidson and P. Kebarle, J. Am. Chem. Soc. 98, 6133 (1976).

${ }^{70}$ I. Dzidic and P. Kebarle, J. Phys. Chem. 74, 1466 (1970).

${ }^{71}$ S. K. Searles and P. Kebarle, Can. J. Chem. 47, 2619 (1969).

${ }^{72}$ J. Sunner, K. Nishizawa, and P. Kebarle, J. Phys. Chem. 85, 1814 (1981).

${ }^{73}$ R. H. Staley and J. L. Beauchamp, J. Am. Chem. Soc. 97, 5920 (1975).

${ }^{74} \mathrm{H}$. Huang and M. T. Rodgers, J. Phys. Chem. A 106, 4277 (2002).

${ }^{75}$ A. W. Castleman, Chem. Phys. Lett. 53, 560 (1978).

${ }^{76}$ M. Sparta and F. Neese, Chem. Soc. Rev. 43, 5032 (2014).

${ }^{77}$ D. G. Liakos, A. Hansen, and F. Neese, J. Chem. Theory Comput. 7, 76 (2011).

${ }^{78}$ E. Paulechka and A. Kazakov, J. Phys. Chem. A 121, 4379 (2017).

${ }^{79}$ E. Paulechka and A. Kazakov, J. Chem. Theory Comput. 14, 5920 (2018).

${ }^{80}$ R. Pollice, M. Bot, I. J. Kobylianskii, I. Shenderovich, and P. Chen, J. Am. Chem. Soc. 139, 13126 (2017).

${ }^{81}$ T. Weymuth, E. P. A. Couzijn, P. Chen, and M. Reiher, J. Chem. Theory Comput. 10, 3092 (2014).

${ }^{82}$ T. Husch, L. Freitag, and M. Reiher, J. Chem. Theory Comput. 14, 2456 (2018).

${ }^{83}$ C. Laurence and J.-F. Gal, Lewis Basicity and Affinity Scales: Data and Measurement (Wiley, Chichester, UK, 2009).

${ }^{84}$ A. Mookherjee and P. B. Armentrout, Int. J. Mass Spectrom. 370, 16 (2014).

${ }^{85}$ W. Y. Feng, S. Gronert, and C. Lebrilla, J. Phys. Chem. A 107, 405 (2003).

${ }^{86}$ C. H. Wu, J. Chem. Phys. 71, 783 (1979).

${ }^{87}$ M. T. Rodgers and P. B. Armentrout, J. Chem. Phys. 109, 1787 (1998).

${ }^{88}$ M. T. Rodgers and P. B. Armentrout, J. Phys. Chem. A 101, 2614 (1997).

${ }^{89}$ M. T. Rodgers and P. B. Armentrout, Int. J. Mass Spectrom. 185, 359 (1999).

${ }^{90}$ J. F. Gal, P. C. Maria, M. Decouzon, O. Mo, and M. Yanez, Int. J. Mass Spectrom. 219, 445 (2002).

${ }^{91}$ R. Amunugama and M. T. Rodgers, J. Phys. Chem. A 106, 5529 (2002).

${ }^{92}$ R. Amunugama and M. T. Rodgers, J. Phys. Chem. A 106, 9718 (2002).

${ }^{93} \mathrm{R}$. Amunugama and M. T. Rodgers, J. Phys. Chem. A 106, 9092 (2002).

${ }^{94} \mathrm{R}$. Amunugama and M. T. Rodgers, Int. J. Mass Spectrom. 227, 1 (2003).

${ }^{95}$ C. H. Ruan, H. Huang, and M. T. Rodgers, J. Am. Soc. Mass Spectrom. 19, 305 (2008).

${ }^{96}$ S. Bourcier, R. X. Chia, R. N. B. Bimbong, and G. Bouchoux, Eur. J. Mass Spectrom. 21, 149 (2015).

${ }^{97}$ G. Bojesen, T. Breindahl, and U. N. Andersen, Org. Mass Spectrom. 28, 1448 (1993).

${ }^{98}$ S. J. Ye, A. A. Clark, and P. B. Armentrout, J. Phys. Chem. B 112, 10291 (2008).

${ }^{99}$ P. B. Armentrout, A. Gabriel, and R. M. Moision, Int. J. Mass Spectrom. 283, 56 (2009).

${ }^{100}$ P. B. Armentrout and M. T. Rodgers, J. Phys. Chem. A 104, 2238 (2000).

${ }^{101}$ A. W. Castleman, K. I. Peterson, B. L. Upschulte, and F. J. Schelling, Int. J. Mass Spectrom. Ion Processes 47, 203 (1983).
${ }^{102}$ M. T. Rodgers and P. B. Armentrout, J. Phys. Chem. A 103, 4955 (1999).

${ }^{103}$ J. C. Amicangelo and P. B. Armentrout, Int. J. Mass Spectrom. 212, 301 (2001).

${ }^{104}$ B. C. Guo, B. J. Conklin, and A. W. Castleman, J. Am. Chem. Soc. 111, 6506 (1989).

${ }^{105}$ S. Hoyau, K. Norrman, T. B. McMahon, and G. Ohanessian, J. Am. Chem. Soc. 121, 8864 (1999).

${ }^{106}$ J. C. Amicangelo and P. B. Armentrout, Int. J. Mass Spectrom. 301, 45 (2011).

${ }^{107}$ M. B. More, D. Ray, and P. B. Armentrout, J. Phys. Chem. A 101, 831 (1997).

${ }^{108} \mathrm{H}$. El Aribi, C. F. Rodriquez, T. Shoeib, Y. Ling, A. C. Hopkinson, and K. W. M. Siu, J. Phys. Chem. A 106, 8798 (2002).

${ }^{109}$ V. Ryzhov and R. C. Dunbar, J. Am. Chem. Soc. 121, 2259 (1999).

${ }^{110}$ C. H. Ruan, Z. B. Yang, N. Hallowita, and M. T. Rodgers, J. Phys. Chem. A 109, 11539 (2005).

${ }^{111}$ N. Hallowita, E. Udonkang, C. H. Ruan, C. E. Frieler, and M. T. Rodgers, Int. J. Mass Spectrom. 283, 35 (2009).

${ }^{112}$ R. M. Moision and P. B. Armentrout, J. Phys. Chem. A 106, 10350 (2002).

${ }^{113}$ P. B. Armentrout, E. I. Armentrout, A. A. Clark, T. E. Cooper, E. M. S. Stennett, and D. R. Carl, J. Phys. Chem. B 114, 3927 (2010).

${ }^{114}$ A. Gapeev and R. C. Dunbar, Int. J. Mass Spectrom. 228, 825 (2003).

${ }^{115}$ M. M. Kish, G. Ohanessian, and C. Wesdemiotis, Int. J. Mass Spectrom. 227, 509 (2003).

${ }^{116}$ C. H. Ruan and M. T. Rodgers, J. Am. Chem. Soc. 126, 14600 (2004).

${ }^{117}$ P. B. Armentrout, M. Citir, Y. Chen, and M. T. Rodgers, J. Phys. Chem. A 116, 11823 (2012).

${ }^{118}$ P. Wang, G. Ohanessian, and C. Wesdemiotis, Int. J. Mass Spectrom. 269, 34 (2008).

${ }^{119}$ S. J. Ye and P. B. Armentrout, J. Phys. Chem. A 112, 3587 (2008).

${ }^{120}$ J. S. Klassen, S. G. Anderson, A. T. Blades, and P. Kebarle, J. Phys. Chem. 100, 14218 (1996).

${ }^{121}$ W. Y. Feng, S. Gronert, and C. B. Lebrilla, J. Am. Chem. Soc. 121, 1365 (1999).

${ }^{122} \mathrm{P}$. Wang, C. Wesdemiotis, C. Kapota, and G. Ohanessian, J. Am. Soc. Mass Spectrom. 18, 541 (2007).

${ }^{123}$ D. H. Evans, R. G. Keesee, and A. W. Castleman, J. Phys. Chem. 95, 3558 (1991).

${ }^{124}$ C. H. Ruan, Z. B. Yang, and M. T. Rodgers, Int. J. Mass Spectrom. 267, 233 (2007).

${ }^{125}$ M. B. More, D. Ray, and P. B. Armentrout, J. Phys. Chem. A 101, 4254 (1997).

${ }^{126}$ J. Sunner and P. Kebarle, J. Am. Chem. Soc. 106, 6135 (1984).

${ }^{127}$ R. Amunugama and M. T. Rodgers, Int. J. Mass Spectrom. 227, 339 (2003).

${ }^{128}$ L. G. Mcknight and J. M. Sawina, J. Chem. Phys. 57, 5156 (1972).

${ }^{129}$ C. Iceman and P. B. Armentrout, Int. J. Mass Spectrom. 222, 329 (2003).

${ }^{130}$ M. T. Rodgers and P. B. Armentrout, J. Phys. Chem. A 101, 1238 (1997).

${ }^{131}$ A. B. Valina, R. Amunugama, H. Huang, and M. T. Rodgers, J. Phys. Chem. A 105, 11057 (2001).

${ }^{132}$ J. S. Smith, O. Isayev, and A. E. Roitberg, Chem. Sci. 8, 3192 (2017).

${ }^{133} \mathrm{M}$. Tsubaki and T. Mizoguchi, J. Phys. Chem. Lett. 9, 5733 (2018).

${ }^{134}$ J. T. Margraf and K. Reuter, J. Phys. Chem. A 122, 6343 (2018).

${ }^{135}$ K. T. Butler, D. W. Davies, H. Cartwright, O. Isayev, and A. Walsh, Nature 559, 547 (2018).

${ }^{136}$ M. Popova, O. Isayev, and A. Tropsha, Sci. Adv. 4, eaap7885 (2018).

${ }^{137}$ X. Chen, M. S. Jorgensen, J. Li, and B. Hammer, J. Chem. Theory Comput. 14, 3933 (2018).

${ }^{138}$ K. T. Schutt, H. E. Sauceda, P. J. Kindermans, A. Tkatchenko, and K. R. Muller, J. Chem. Phys. 148, 241722 (2018).

${ }^{139}$ L. F. Zhang, J. Q. Han, H. Wang, R. Car, and E. Weinan, Phys. Rev. Lett. 120, 143001 (2018).

${ }^{140}$ K. Yao, J. E. Herr, D. W. Toth, R. Mckintyre, and J. Parkhill, Chem. Sci. 9, 2261 (2018).

${ }^{141}$ I. Minenkova, V. V. Sliznev, L. Cavallo, and Y. Minenkov, Inorg. Chem. 58, 7873 (2019). 